\title{
Effects of celebrity endorsement on customer trust and loyalty: Case study on pilgrims in Aceh
}

\author{
Ricky Alfanda ${ }^{1}$ and Pratiwi Dwi Suhartanti ${ }^{2}$ \\ ${ }^{1}$ College of Doctoral Management Science, Syiah Kuala University, Banda Aceh \\ ${ }^{2}$ College of Master Management, Syiah Kuala University, Banda Aceh \\ Correspondence email :pratiwi482@gmail.com
}

\begin{abstract}
The increasing of fraud cases against umrah pilgrims in Indonesia, causing travel companies to be observant in doing their marketing. One of their marketing strategies is to increase the trust and loyalty of pilgrims to their travel companies. To increase customer trust and loyalty, travel companies use celebrity endorsement to help promote their products. In Aceh, many travel companies use celebrity endorsement to assist the promotion of their umrah packages. The people of Aceh are known as a society that implements Islamic shariah as the foundation of their life. Many Islamic Boarding School (pesantren) leaders, mosque imams, and influential public figures have become celebrity endorsements. They are believed to be able to make people believe to do umrah with travel companies that use them as celebrity endorsements. The purpose of this study was to examine important criteria in creating customers' loyalty. The relationship between celebrity endorsement and trust are investigated for this purpose. This study discussed how celebrity endorsement affected customer trust and its impact on customer loyalty umrah pilgrims in Aceh. A sample was drawn from umrah pilgrims in Aceh with 218 respondents. Primary data was used in this study in form of questionnaire with Likert scale. SPSS was used to analyze demographic characteristics of the respondents and descriptive analysis. AMOS 22 was adopted for the Structural Equation Modeling of the survey model for verified analysis using regression weight/loading factor. The findings of this study have shown significant relationships among the variables under investigation. Customers' trust was found as moderate variable between celebrity endorsement and customers' loyalty. The results of this study could provide input for travel companies in Aceh to use celebrity endorsement if they wanted to increase customer trust and loyalty of Umrah pilgrims.
\end{abstract}

Keywords: celebrity endorsement, trust, loyalty, Umrah pilgrims, Aceh 


\section{Introduction}

Based on the journal written by Siti Hasnah Hassan et al., (2016), religious tourism is one of the oldest forms of tourism and is motivated by religious or spiritual commitment (Sharpley, 2009). It is uniquely different from other forms of tourism because it is motivated by a sense of duty and obligation rather than the pursuit of pleasure and leisure (Swarbrooke and Horner, 2007). Religious attendance strengthens and ensures a person's religious commitments and the particular narrative of their experience. In Islam, religious and spiritual journeys can be divided into three forms of activities (Haq and Wong, 2010; Timothy and Olsen, 2006). The first activity is performing Hajj, including Umrah, which is among the fundamental Islamic practices and institutions known as the five pillars of Islam. It is compulsory for all Muslims to visit Mecca from the specific time frame of the 8th to 12th Dhu al-Hijjah. The second spiritual journey is Rihla, the journey in search of knowledge, commerce, health, or research. The third activity is called Ziyara, which is to visit holy places such as shrines, mosques, or monasteries for spiritual growth (Timothy and Olsen, 2006).

By doing a hajj, a Muslim has done the fifth pillar of Islam and is said to fulfill or complete its Islam or faith. It is because Muslims need to perform a series of rituals and it gives highly spiritual experience towards them. Meanwhile, Umrah is a non-mandatory lesser pilgrimage or Sunna for Muslims. It aims to make Muslims get closer to The Creator. Hajj and Umrah only differ at the time of the performance and negation of some rituals that can only be done in Hajj month.

Both hajj and Umrah are categorized as high involvement products. It is reinforced by the result of interviews that the researchers did to some sources that had done both hajj and umrah using Special Hajj and Umrah Travel company. They said that Hajj and Umrah are expensive, important, high-risk and need much informational consideration which results in a long search of information. The information is searched so it can be used as the evaluation process towards various alternatives of Special Hajj and Umrah Travel Company provided in the market (Kamins, 2007).

The source of information consists of internal and external sources. Both types of information source tend to be different in use depending on the situation that the customers have. As an example, external information source depends on some factors such as market characteristics, product characteristics, customers' characteristics and situation characteristics (Ohanian, 2007).

The various numbers of hajj and umrah travel agencies getting involved in the Hajj and Umrah create competitions among one another. It also makes pilgrims a bit confused in choosing the best travel company in giving service for all fields so Hajj and Umrah can be done maximally and brings satisfying results to the customers. Provision of good service to pilgrims will give trust to the pilgrims which finally create pilgrims' loyalty towards the travel company concerned.

The growing economy and rapid thriving business activities demand companies develop and improve their marketing strategy to attract and maintain their customers (Jaeil et al., 2013). Marketing strategy is a marketing logic in which the 
companies hope to create the value of customers and reach profitable relationship (Kotler, 2008). In relationship marketing, companies do not seek immediate sales but the long-term supplier-customer relationship (Kotler \& Keller, 2012). If it is properly implemented, they will focus on managing their customers. It is an ongoing relationship between buyer and seller (Dwyer, Schurr \& Oh, 1987). Despite the same products being offered, the right promotion to the market target will make the products easy to be accepted by candidate customers. Some things that the companies need to consider to attract customers are advertisement media and the person who starred in the advertisement (celebrity endorser).

Celebrities will attract customers' attention and the products being endorsed by them will be easier to remember. To create image and customers' trust, the celebrity endorsers have to be selected in accordance with the endorsers' characters and customs or habits. Babu conducted a research (2014) saying that celebrity endorser could influence customers in the purchase.

In Aceh, celebrity endorsers are used to helping promote umrah and special hajj packages, usually being offered by travel companies. The phenomenon that will happen is that Hajj and Umrah pilgrims will give their trust and be more satisfied if their pilgrimage is accompanied and guided by special people such as ustadz, ulama, and Tengku that they believe in. Guides of umrah and special hajj are promotion tools for Umrah and Special Hajj Travel Companies. Competent and knowledgeable in religion guides and those with good ability of da'wah are expected to give comfort to customers when doing their Umrah and Hajj, so they can attract customers' interest.

Advertisements of a Special Hajj and Umrah Travel Company often display the name of umrah guide clearly. The Umrah guide is usually a religious leader or a celebrity who are well-known to the public. It is a strategy of a Special Hajj and Umrah Travel Company in selling its programs to the customers.

As an example, some Special Hajj and Umrah Travel Companies often use a leader of Islamic Boarding School (pesantren) in Aceh. Thus, Umrah pilgrims that once studied in the Islamic Boarding School concerned will be happier in using travel companies that ask the Islamic Boarding School leaders as their umrah guide. The function of Hajj and Umrah guide can be synchronized with the function of an actor in promoting his movie. According to Albert (2007), actors can be categorized as stars due to several reasons: They have the ability in acting, have prominent nature that can attract customers, can be free publications and can secure investments. In other words, it can be said that actors are lucky people. Those functions are expected to appear in a Special Hajj and Umrah guide. They are expected not only to be guides but also to lift the image and/ or sales of a Special Hajj and Umrah Travel Company. Hence, the purpose of the study is to see and/ or observe roles of celebrity endorser that the Special Hajj and Umrah Travel companies use in Aceh as a moderate variable that influences the relationship between Special Hajj and Umrah pilgrims' trust and loyalty. 


\section{Literature Review}

\subsection{Celebrity Endorsement}

Celebrities are defined as famous individuals who reach fame that makes them popular and well known to the public. Culture development in the society makes them curious about the celebrities' personality (Young and Pinsky, 2006). As a popular and well-known person, a celebrity is often used to support an advertisement. Approximately one out of six advertisements in the world use celebrities in their advertisements.

Celebrity endorser is a promotion which companies do in using celebrities as supporters in the advertising media to advertise a product. Byun (2014) categorizes five components of celebrity endorser:

1. Credibility

2. Attractiveness

3. Expertise

4. Trustworthiness

5. Celebrity Match-Up Product

In travel companies, personal endorsement holds a very important role. Umrah pilgrims will be happier and gladder if they do their pilgrimage with trusted ustadz or religious leader (ulama). Hence, the company that uses the right endorser will be chosen or liked more by the Umrah pilgrims.

\subsection{Customer Trust}

Trust is a condition in the marketing to maintain the relationship between customers and service providers as customers have to make a purchase decision before they completely get the service (Berry \& Parasuraman, 2013).

The organization describes trust as a whole faith regarding organizational competency in terms of communication and behavior, in terms of openness and honesty, concern and reliability. In addition, individuals think that they have got the same purposes, norms, and values so they deserve to be identified (Zalabak et al., 2010).

Parvez (2009) did a research on the influence of service quality, trust, and satisfaction towards customers' loyalty in a big communication company in Bangladesh. The research showed that customers' trust and satisfaction significantly and positively influenced customers' loyalty. Customers' satisfaction had been found as an important mediator between service quality that the customers experience and their loyalty. On the other hand, trust has become an important point in influencing customers' loyalty of the cellular service providers. If their customers' trust was not kept despite their good service, their customers would be hesitant to be loyal to the service provider. In his journal, Parvez (2009) also stated that some researchers 
had suggested that trust is a fundamental variable in developing customers' loyalty. Additionally, many other researchers found out that trust was very important in influencing customers' loyalty.

Hajj and Umrah Travel Company is expected to create good stimuli, in which the stimuli are closely related to the effort of a process of designing a reliable service, so it will help push commitment and trust of its customers.

Indicators that are used to measure customers' trust towards Hajj and Umrah Travel Agency refer to Shamdasani and Balakrishnan (2010):

1. The Travel Agency can be trusted / reliable.

2. The trust on comfort in traveling.

3. The trust on transport quality that the travel agency has

4. The trust that the travel agency provides the best service or as promised.

\subsection{Customer Loyalty}

According to Griffin (2015), loyalty is a form of behavior from units of decision makers in doing continuous purchase upon goods or service from chosen companies. Loyalty is a form of behavior from units of decision makers or customers' commitment to buy, consume or use goods or service continuously from a chosen company within an uncertain period of time.

Dick \& Basu (2014) stated that loyalty is the behavioral response being expressed over time through a decision that is made among available alternatives. According to Griffin (2015), customers' loyalty is behavior compared to attitude, a loyal customer will pay attention to purchase attitude that can be defined as regular purchase pattern in a long time, which is done by units of decision makers.

Loyal customers are invaluable assets to the company. Griffin (2015) defined loyal characteristics as (1) doing repeat purchases, (2) purchasing across product lines, (3) inviting other people to use the same product or service (referrals), and (4) rejecting other competitors' products (retention).

Indicators that can be used in reference to Griffin's opinion (2015) are: (1) using travel agency service actively, (2) inviting other people to visit the travel agency, (3) telling other people about the positive image of the travel agency, and (4) retention towards competitor travel agencies as the customers think that the travel agency is trustworthy.

Trust influences customers and commitment towards Word of Mouth (WOM), intention to re-purchase and price insensitivity. Besides, customers' trust influences customers' loyalty (Shamdasani, 2010).

Indicators of Special Hajj and Umrah customers' loyalty are:

1. Repeat Purchase: loyalty in re-using the travel agency in the nex umrah pilgrimage 
2. Retention: immunity towards negative influence about companies. Despite many fraud cases involving Special Hajj and Umrah Travel Agencies, very loyal customers will not be influenced and may still use the service

3. Referrals: totally referring the existence of Special Hajj and Umrah Travel Agencies being used (Ahmad Mardalis, 2015).

\subsection{Research Model and Hypothesis}

The description of thought in prior has built background and direction for the theoretical research model arrangement. The research model is used in the research is depicted in the following scheme:

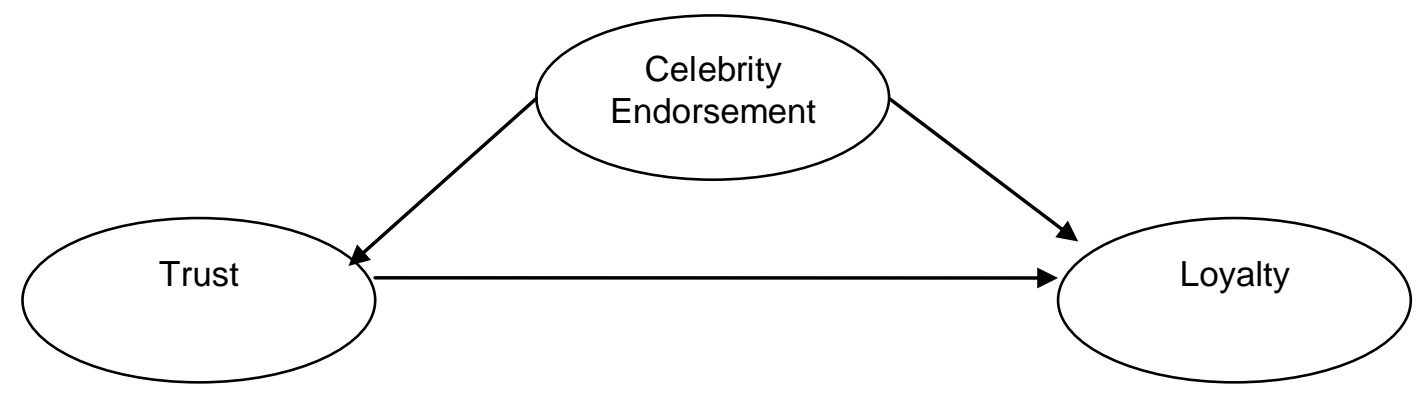

Picture 1. Research Model

Based on the picture above, it can be seen that the paradigm of the study expects that customer trust will influence customer loyalty, and celebrity endorsement will influence the relationship between the customer trust and customer loyalty of Special Hajj and Umrah Travel Companies in Aceh.

Seeing the problems and literature review, a hypothesis of the study can be formulated as the followings:

H1: Customer trust, celebrity endorsement, and customer loyalty of Special Hajj and Umrah Travel Company in Aceh are at a good level.

H2: Celebrity Endorsement influences customer trust of Special Hajj and Umrah Travel Company in Aceh.

H3: Customer trust influences customer loyalty of Special Hajj and Umrah Travel Company in Aceh.

H4: Celebrity Endorsement influences customer loyalty of Special Hajj and Umrah Travel Company in Aceh.

H5: Celebrity Endorsement influences the relationship between customer trust and customer loyalty of Special Hajj and Umrah Travel Company in Aceh.

\section{Methodology}




\subsection{Location of the Study}

The analysis and observation units of the study were pilgrims of Special Hajj and Umrah in Aceh. The study was conducted on a time horizon by also using one snapshot cross-section as its data type. The study was designed in descriptive and validating. Descriptive studies aim to get pictures or descriptions on pilgrims' trust, celebrity endorsement, and pilgrims' loyalty. The gained data will be elaborated in terms of numbers or figures, percentage, and tables so they are easy to understand and interpret. Validating researchers aim to know the relationship among variables through hypothesis tests by using statistical calculations (Nazir, 2011).

In collecting the data, the study used survey descriptive and survey validating methods. Through these methods, descriptions of variables being studied and their relationships can be seen clearly. Survey method being used in the study was by doing measurement towards quantitative and qualitative characteristics of their analysis units. The survey concerned was conducted to the chosen population. In the survey technique, the information is gathered from respondents by using questionnaires (Arikunto, 2010).

\subsection{Population and Samples}

The population of the study was all pilgrims of Umrah in Aceh who have done their Umrah within the last 1 year $(2016$ - 2017) on licensed Umrah Travel Companies (Companies that have got an official license from Ministry of Religion to conduct Umrah).

Among all Umrah Travel Companies, only 5 companies in Aceh have got a license. Hence, the population of the study was all pilgrims in 5 companies that did their Umrah within 2016-2017. There were a total number of 490 pilgrims being involved in the study. Since the total population is known, Slovin formula can be used to determine the sample numbers with the value of $e=0,05$, (Sekaran, 2010). The formulation is as the following:

$$
\begin{aligned}
& n=N /\left(1+N e^{2}\right) \\
& n=490 /\left(1+490 \times 0,05^{2}\right) \\
& n=490 / 2,225 \\
& n=220 \text { sample }
\end{aligned}
$$

\section{Notes:}

n : sample size

$\mathrm{N}$ : population size

e : tolerable inaccuracy percentage due to sampling, as many as 0,05

The total sampling needed to be was distributed proportionally to 5 licensed Umrah Travel Agency companies in Aceh. The distribution used the following formula: 


$$
n i=(N i / N) \times n
$$

Notes:

ni : Number of samples in each Travel Company

$\mathrm{Ni}$ : Size of pilgrims in each Travel Company

$\mathrm{N}$ : Total number of pilgrims in Travel Company

$\mathrm{n} \quad$ : Size of research samples

Thus, a number of samples in licensed Umrah Travel companies in Aceh and West Sumatera is depicted in the following table:

Table 1

Number of Samples in each Umrah Travel Company

\begin{tabular}{|l|l|c|c|c|}
\hline No & \multicolumn{1}{|c|}{ Name of Travel Company } & Location & Population & Sample \\
\hline 1 & PT. Asra Prima Travel Tour & Banda Aceh & 50 & 23 \\
\hline 2 & PT. Natari Tour \& Travel & Lhokseumawe & 65 & 30 \\
\hline 3 & PT. Dian Almaaz Wisata & Banda Aceh & 80 & 36 \\
\hline 4 & PT. Mafaza Tour \& Travel & Banda Aceh & 30 & 14 \\
\hline 5 & PT. Lintas Iskandaria & Banda Aceh & 265 & 117 \\
\hline \multicolumn{2}{|c|}{ Total } & 490 & 220 \\
\hline
\end{tabular}

Source: Primary Data (2017)

\subsection{Tools of Data Analysis}

Primary data was used in the study in the form of a questionnaire with Likert scale. SPSS and descriptive analysis were used to analyze demographic characteristics of the respondents. Varian or Component-based Structural Equation Modeling (SEM), AMOS 22.0, was used as the analysis tool in validating research. The equation model of SEM is a group of statistical techniques which enable tests towards a relatively and simultaneously complicated relationship (Ferdinand, 2014). To conduct testing of significance towards the indirect effects from exogenous variable to an endogenous variable through moderating variable, the researcher used Sobel test. To get the value of Sobel, Calculator Sobel test application was used by also inputting value of role (Estimate) and its standard error (S.E) from its path.

\subsection{Test Design}

\subsubsection{Validity Test}

Validity test was used to measure whether a questionnaire is valid or not. When a questionnaire is valid, its instrument can be used to measure what to measure. The validity used in the study depicted concord of a gauge and what to measure. The validity test in the study was conducted by correlating each score of each item of the 
questions with the total score of all question items. The correlation technique used to validate each question in the study was Pearson Product Moment correlation. If the coefficient value of each question item being tested is bigger than critical $(0,3)$, it can be concluded that the question item is a valid construct.

Table 2. Result of Validity Test in Questionnaire

\begin{tabular}{|c|c|c|c|c|}
\hline Variable & Question Item & $\mathbf{r}_{\text {count }}$ & $\mathbf{r}_{\text {critical }}$ & Note \\
\hline \multirow{4}{*}{ Customer Trust } & $\mathrm{A} 1$ & 0,564 & 0,3 & valid \\
\cline { 2 - 5 } & $\mathrm{A} 2$ & 0,654 & 0,3 & valid \\
\cline { 2 - 5 } & $\mathrm{A} 3$ & 0,800 & 0,3 & valid \\
\cline { 2 - 5 } & $\mathrm{A} 4$ & 0,584 & 0,3 & valid \\
\cline { 2 - 5 } & $\mathrm{A} 5$ & 0,681 & 0,3 & valid \\
\cline { 2 - 5 } & $\mathrm{A} 6$ & 0,658 & 0,3 & valid \\
\hline & $\mathrm{B} 1$ & 0,634 & 0,3 & valid \\
\cline { 2 - 5 } & $\mathrm{B} 2$ & 0,509 & 0,3 & valid \\
\cline { 2 - 5 } & $\mathrm{B} 3$ & 0,339 & 0,3 & valid \\
\cline { 2 - 5 } & $\mathrm{B} 4$ & 0,548 & 0,3 & valid \\
\cline { 2 - 5 } & $\mathrm{B} 5$ & 0,312 & 0,3 & valid \\
\cline { 2 - 5 } & $\mathrm{B} 6$ & 0,708 & 0,3 & valid \\
\cline { 2 - 5 } & $\mathrm{B} 7$ & 0,563 & 0,3 & valid \\
\cline { 2 - 5 } & $\mathrm{B} 8$ & 0,453 & 0,3 & valid \\
\cline { 2 - 5 } & $\mathrm{B} 9$ & 0,390 & 0,3 & valid \\
\cline { 2 - 5 } & $\mathrm{B} 10$ & 0,432 & 0,3 & valid \\
\hline \multirow{4}{*}{ Customer Loyalty } & $\mathrm{C} 1$ & 0,816 & 0,3 & valid \\
\cline { 2 - 5 } & $\mathrm{C} 2$ & 0,752 & 0,3 & valid \\
\cline { 2 - 5 } & $\mathrm{C} 3$ & 0,436 & 0,3 & valid \\
\cline { 2 - 5 } & $\mathrm{C} 4$ & 0,375 & 0,3 & valid \\
\cline { 2 - 5 } & $\mathrm{C} 5$ & 0,701 & 0,3 & valid \\
\hline
\end{tabular}

Source: Result of Study (processed 2017)

Based on Table 2, it can be seen that the value of all question items in the questionnaire is more than $r_{\text {critical }}\left(r_{\text {count }}>0,3\right)$. Hence, it can be concluded that all question items are valid or proper to use as a measurement tool in the study.

\subsubsection{Reliability Test}

Reliability test is actually a test to measure a questionnaire that becomes an indicator of a variable or a construct. A questionnaire is said as reliable if someone's answers towards the questions were consistent or stable over time (Ghozali, 2014). One shot or one measurement only means the measurement is only done once and the result is then compared to other statements or to measure correlation among answers.

The result of a reliability test in the study is as the following: 
Table 3. Result of Reliability Test in Questionnaire

\begin{tabular}{|l|c|c|c|}
\hline \multicolumn{1}{|c|}{ Variable } & Reliability Index & $\begin{array}{c}\text { Critical } \\
\text { Value }\end{array}$ & Notes \\
\hline Customer Trust & 0,923 & 0,7 & reliable \\
\hline $\begin{array}{l}\text { Celebrity } \\
\text { Endorsement }\end{array}$ & 0,871 & 0,7 & reliable \\
\hline Customer Loyalty & 0,929 & 0,7 & reliable \\
\hline
\end{tabular}

Source: Result of Study (processed 2017)

SPSS gives a facility of measuring reliability with Cronbach Alpha ( $\alpha$ ) statistical test. A construct or variable is said as reliable if the value of Cronbach Alpha is $>0,7$. Based on Table 3, it can be noticed that the reliability value of all question items in each questionnaire of each variable being studied is more than 0,7 . The result shows that statement item in the questionnaire were reliable to measure their variables.

\subsubsection{Hypotheses Testing}

After the model meets the conditions and requirements, the next step to do is regression weight/loading factor test.

1. Descriptive hypotheses testing. This hypothesis is determined by seeing the average respondents' responses towards the statements. If the average value of respondents' responses is $\geq 4$, Ho is not denied, but if the average value of respondent's responses is $<4$, Ho is denied.

2. The hypothesis testing is based on the CR value on the level of trust of $95 \%$. If the CR value is $>1,96$ and $P$ value is $>0,05$, Ho is not denied and if the $C R$ value is $<1,96$ and $P$ value is $>0,05$, Ho is denied.

\section{Findings and Discussion}

Based on recent reports, Muslims are one of the largest targets of the tourism sector since the Muslim population comprises a global market of 2.1 billion potential consumers (Muslim Population Worldwide, 2014). In general, although religious-based tourism is expanding, there is not much information about the phenomenon of religious tourism, particularly pilgrimage tourism such as Umrah (Egresi et al., 2012). Research on this thriving sector is limited, thus knowledge about this trend remains scarce. Until recently, relatively little attention has been given to the subject matter in tourism literature because of the complex relationship between tourism and religion. Researchers are now taking an interest in the study of religious tourism and the associated issues concerning the service quality provided by the tour operators. 
The significant growth of this industry has attracted the attention of marketers to invest largely in understanding Muslim tourist's needs and their intention towards the traveling packages. Consequently, to fully understand what motivates pilgrims to purchase Umrah packages, the tour providers need to recognize the factors that affect the behavior of Muslim travelers in regards to their trust and loyalty. Previous literature has provided insights from other industries, such as services in general, which might be relevant to the religious tourism with regards to identifying the predicting factors.

Table 1 depicts the demographic profile of 220 respondents. The demographic profile includes the respondent's gender, age, marital status, education level, income, occupation and how many times do umroh using this travel.

Table 4

Demographic profile of respondents $(n=220)$

\begin{tabular}{|c|c|c|c|}
\hline \multicolumn{2}{|r|}{ Categories } & Frequency & Percentage \\
\hline \multirow[t]{2}{*}{ Gender } & Male & 141 & 64.1 \\
\hline & Female & 79 & 35.9 \\
\hline \multirow[t]{5}{*}{ Age } & $21-30$ & 21 & 9.6 \\
\hline & $31-40$ & 116 & 52.7 \\
\hline & $41-50$ & 53 & 24.1 \\
\hline & $51-60$ & 30 & 13.6 \\
\hline & $>60$ & & \\
\hline \multirow{2}{*}{$\begin{array}{l}\text { Marital } \\
\text { Status }\end{array}$} & Married & 134 & 60.9 \\
\hline & Single & 86 & 39.1 \\
\hline \multirow{4}{*}{$\begin{array}{l}\text { Education } \\
\text { level }\end{array}$} & Diploma & 14 & 6.4 \\
\hline & Degree & 146 & 66.3 \\
\hline & Masters & 53 & 24.1 \\
\hline & Others & 7 & 3.2 \\
\hline \multirow[t]{5}{*}{ Income } & Rp. $4.000 .000-5.999 .000$ & 8 & 3.6 \\
\hline & Rp. $6.000 .000-6.999 .000$ & 18 & 8.2 \\
\hline & Rp. $7.000 .000-7.999 .000$ & 77 & 35.0 \\
\hline & Rp. $8.000 .000-8.999 .000$ & 67 & 30.5 \\
\hline & $>$ Rp. 9.000 .000 & 50 & 22.7 \\
\hline \multirow[t]{4}{*}{ Occupation } & Government sector & 145 & 65.9 \\
\hline & Private sector & 37 & 16.8 \\
\hline & Owned-business & 26 & 11.8 \\
\hline & Others & 12 & 5.5 \\
\hline \multirow{5}{*}{$\begin{array}{l}\text { How many } \\
\text { times do } \\
\text { umroh using } \\
\text { this travel }\end{array}$} & 2 & 121 & 55.0 \\
\hline & 3 & 69 & 31.4 \\
\hline & 4 & 15 & 6.8 \\
\hline & 5 & 11 & 5.0 \\
\hline & $>5$ & 4 & 1.8 \\
\hline
\end{tabular}

According to Table 1, the results showed that the majority of respondents are male $(64,1 \%)$ and middle-aged. The majority of the respondents are married $(60,9 \%)$ and educated are bachelor degree $(66,9 \%)$. The majority of the respondents have a monthly salary of between Rp. 7.000.000 and Rp.9.000.000. The majority of the respondents work within the government sector $(65,9 \%)$. The 
majority of respondents performed Umrah twice $(55,0 \%)$, and three times $(31,4 \%)$ the others respondents performed more than three times.

Descriptive data is to display a general description of respondents' answers to the statements contained in the questionnaire. Description of the research data can be used to enrich the discussion, through the description of the data can be known how the responses of respondents to each variable being studied. Based on responses from 220 respondents about the research variables, the researchers will describe in detail the respondents' answers grouped in descriptive statistics. Empirical description of the data used in the study descriptively using the mean (mean). Through the mean number will be known to what degree of respondent perceptions of the variables that become indicators in this study. To make it easier to interpret the variables being studied, categorization of respondents score was done. Descriptive analysis is done referring to each indicator that is on the variables studied.

Descriptive analysis will be used to test the hypothesis by looking at the average value of the respondent's response to the statement, if the average value of respondents $\geq 4$ then Ho is not rejected, and if the average value of respondents $<4$ then $\mathrm{Ho}$ is rejected.

Table 4

Descriptive Analysis Result

\begin{tabular}{|l|c|}
\hline \multicolumn{1}{|c|}{ Indicator } & Average Answer \\
\hline Customer Trust & 4,23 \\
\hline Celebrity Endorsement & 4,37 \\
\hline Customer Loyalty & 4,48 \\
\hline
\end{tabular}

Source: Primary Data, 2017 (processed)

It is seen in Table 4 that average value of respondents' answers towards variables being used in the study such as customer trust, celebrity endorsement and customer loyalty shown are good. It is clearly shown as the average value of respondents' answer is $\geq 4$.

Consumer loyalty indicates the predetermined attitude relating to the good or service which comprises the probability of future service contracts, how likely consumers are to change establishments and spread positive word-of-mouth, or the possibility of the consumers giving out their opinions (Andreassen and Lindestad, 1998). Satisfied consumers often tend to be loyal and thus would want to pursue different services. As a consequence, satisfied consumers intended to recommend the product or service to others and would like to revisit the place (Kozark and Rimmington, 2000).

Table 5

Result of Goodness of Fit Test

\begin{tabular}{|l|l|l|l|}
\hline Goodness of Fit Index & Cut-off Value & Result & Model Evaluation \\
\hline Chi-square & Expected small & 326.671 & Good Fit \\
\hline Significance probability & $\geq 0.05$ & 0,077 & Good Fit \\
\hline CMINDF & $\leq 2.00$ atau $\leq 3.00$ & 2,372 & Good Fit \\
\hline
\end{tabular}




\begin{tabular}{|l|l|l|l|}
\hline GFI & $\geq 0.90<1$ & 0,967 & Good Fit \\
\hline AGFI & $\geq 0.90<1$ & 0,954 & Good Fit \\
\hline PGFI & $\geq 0.50<1$ & 0,505 & Good Fit \\
\hline NFI & $\geq 0.95<1$ & 0,928 & Fit \\
\hline RFI & $\geq 0.95<1$ & 0,969 & Good Fit \\
\hline IFI & Approaching 1.0 & 0,962 & Fit \\
\hline TLI & $\geq 0.95<1$ & 0,978 & Good Fit \\
\hline CFI & $\geq 0.95<1$ & 0,912 & Fit \\
\hline RMSEA & $0.03-0.08$ & 0,045 & Good Fit \\
\hline
\end{tabular}

Based on the result of the goodness of fit test above Table 5 depicted that the model has fulfilled some indicators of goodness of fit so model modification does not need to be done.

Table 6

Result of Model Estimation

Regression Weights: (Group number 1 - Default model)

\begin{tabular}{|c|c|c|c|c|c|c|c|}
\hline & & & Estimate & S.E. & C.R. & & Label \\
\hline Customer_Trust & $<---$ & Celebrity_Endorsement & .596 & .062 & 9.566 & 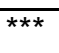 & par_21 \\
\hline Customer_Loyalty & $<---$ & Customer_Trust & 1.152 & 221 & 5.202 & *** & par_14 \\
\hline Customer_Loyalty & $<---$ & Celebrity_Endorsement & .100 & .123 & 4.808 & *** & par_15 \\
\hline C1 & $<--$ & Customer_Loyalty & 1.000 & & & & \\
\hline C2 & $<---$ & Customer_Loyalty & .893 & .108 & 8.260 & *** & par_1 \\
\hline C3 & $<---$ & Customer_Loyalty & .867 & .098 & 8.859 & *** & par_2 \\
\hline C4 & $<---$ & Customer_Loyalty & .840 & .094 & 8.897 & *** & par_3 \\
\hline C5 & $<---$ & Customer_Loyalty & 1.104 & .116 & 9.547 & *** & par_4 \\
\hline A1 & $<---$ & Customer_Trust & 1.000 & & & & \\
\hline A2 & $<---$ & Customer_Trust & 1.387 & 129 & 10.752 & *** & par_5 \\
\hline A3 & $<---$ & Customer_Trust & 1.473 & 132 & 11.175 & *** & par_6 \\
\hline A4 & $<---$ & Customer_Trust & 1.293 & 127 & 10.213 & *** & par 7 \\
\hline A5 & $<---$ & Customer Trust & 1.593 & .141 & 11.291 & *** & par 8 \\
\hline A6 & $<---$ & Customer_Trust & 1.302 & .125 & 10.451 & *** & par_9 \\
\hline B1 & $<---$ & Celebrity_Endorsement & 1.000 & & & & \\
\hline B2 & $<--$ & Celebrity_Endorsement & .787 & .083 & 9.436 & *** & par_10 \\
\hline B3 & $<---$ & Celebrity_Endorsement & .847 & .084 & 10.037 & *** & par_11 \\
\hline B4 & $<---$ & Celebrity_Endorsement & .816 & .087 & 9.361 & *** & par_12 \\
\hline B5 & $<---$ & Celebrity_Endorsement & 1.111 & .099 & 11.201 & $\star * *$ & par_13 \\
\hline B6 & $<---$ & Celebrity_Endorsement & 1.087 & .094 & 11.610 & *** & par_16 \\
\hline B7 & $<---$ & Celebrity_Endorsement & 1.066 & .097 & 10.982 & *** & par_17 \\
\hline B8 & $<---$ & Celebrity_Endorsement & .978 & .088 & 11.060 & *** & par_18 \\
\hline B9 & $<--$ & Celebrity_Endorsement & 1.085 & .091 & 11.891 & $\star \star \star *$ & par_19 \\
\hline B10 & $<--$ & Celebrity_Endorsement & .868 & .093 & 9.303 & $* * *$ & par_20 \\
\hline
\end{tabular}

Based on the estimated result in prior, some conclusions can be drawn as the followings:

1. Celebrity endorsement affected significantly towards customer trust at Special Hajj and Umrah Travel Company in Aceh. It is because probability value is less than $0,05\left({ }^{* * *}<0,05\right)$ and $C R$ values is $9,566(C R>1,96)$. The value if positive estimation is 0,596 which means the effect is positive, or in other 
words, if Celebrity endorsement is improved, customer trust will also be improved.

2. Customer trust affected significantly towards Customer loyalty at Special Hajj and Umrah Travel Company in Aceh. It is shown with the value of probability that reaches less than $0,05\left({ }^{* * *}<0,05\right)$ and the value of $C R$ as many as 5.202 $(C R>1,96)$. The positive estimation value reaches 1,152 , which means the influence is positive. In other words, if customer trust improves, Customer loyalty will also improve.

3. Celebrity endorsement affected customer trust at Special Hajj and Umrah Travel Company in Aceh significantly. This was presented by the probability value that reaches less than $0,05\left({ }^{* * *}<0,05\right)$ and the value of $C R$ as much as $4,808$ ( $C R>1,96)$. The value if positive estimation is 0,100 in which the influence is positive. This also means that if Celebrity endorsement is improved, customer loyalty will also be improved.

Based on the coefficient result of regression conducted, it can be concluded that there were direct influences from various variables being studied. It can be clearly seen in the following picture (Picture 1).

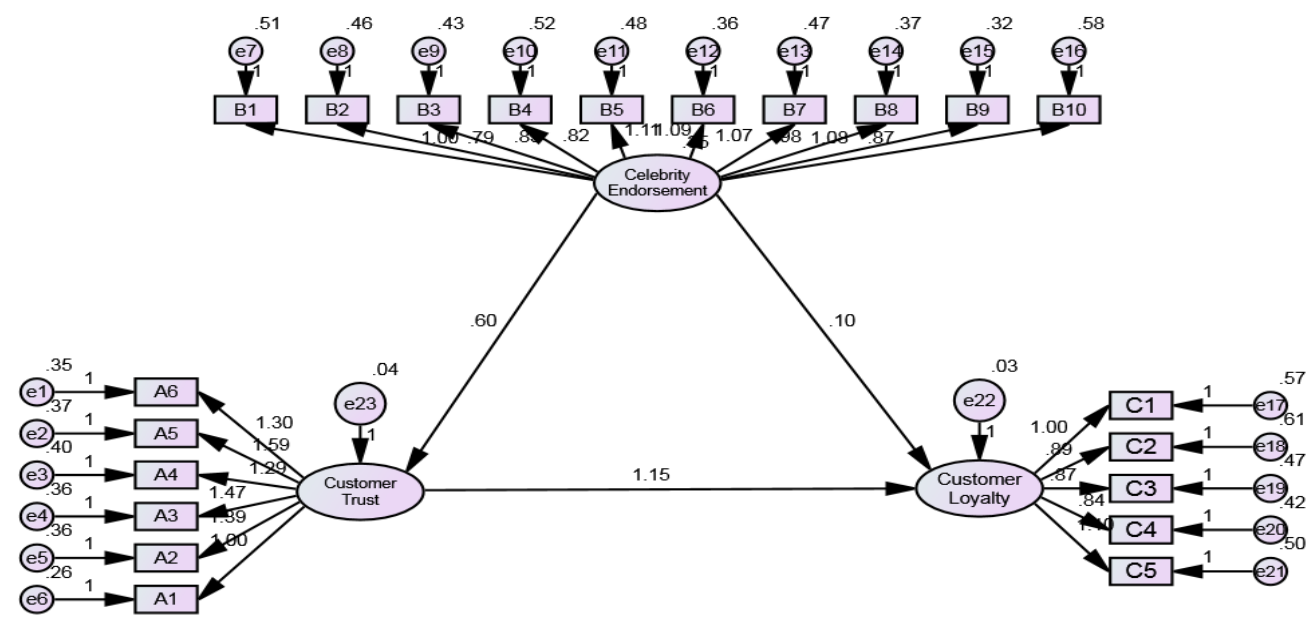

Picture 1. Path Diagram

We can see the adjusted R-square to know the contribution of exogenous variable towards endogenous variables. Determination coefficient (R2) basically measures how far the model can explain endogenous variables.

It is distinguished that variable of customer trust is affected by celebrity endorsement. The value of R-square of customer trust variable is 0,749 , which 
means that celebrity endorsement contributed as much as $74,9 \%$ towards customer trust, while the rest is influenced by other factors than those variables.

The variable of customer loyalty is affected by the variables of customer trust and celebrity endorsement. The value of R-square of customer loyalty variable is 0,889 , which means variables of customer trust and celebrity endorsement contributed as much as $88,9 \%$ to customer loyalty, while the rest is influenced by other factors than those variables.

To know whether the indirect influence of $X 1$ towards $Z$ through $Y$ and $X 2$ towards $Z$ through $Y$, is significant or not, Sobel test is conducted. Sobel test was used to know the indirect influence of mediation variables. To get the value of Sobel, Calculator Sobel test application was used. Based on the result of Sobel test we know if the indirect influence of customer trust towards customer loyalty through celebrity endorsement was significant because the significance value is $0,021<0,05$. Hence, the variable of celebrity endorsement mediated the influence of customer trust towards customer loyalty.

\section{Conclusion}

According to the result of data analysis in the fourth chapter, some conclusions can be drawn as the followings:

1. Customer trust, celebrity endorsement, and customer loyalty of Special Hajj and Umrah Travel Company in Aceh are at a good level.

2. Celebrity endorsement affected significantly towards customer trust at Special Hajj and Umrah Travel Company in Aceh. The value of the influence was positive, in which customer trust will improve if celebrity endorsement improves.

3. Customer trust affected significantly towards customer loyalty at Special Hajj and Umrah Travel Company in Aceh. The value of the influence was positive, in which customer loyalty will improve if customer trust improves.

4. Celebrity endorsement affected customer trust at Special Hajj and Umrah Travel Company in Aceh significantly. The value of influence was positive, which means customer trust will improve if celebrity endorsement improves.

5. Customer trust influenced significantly towards customer loyalty at Special Hajj and Umrah Travel Company in Aceh through celebrity endorsement. Hence, the variable of celebrity endorsement mediated the influence of customer trust towards customer loyalty.

\section{REFERENCES}

Abd-el-salam, E. M., \& Shawky, A. Y. 2013. The impact of corporate image and reputation on service quality, customer satisfaction, and customer loyalty: testing the mediating role. Case analysis in an international service company. 3(2) 177-196.

Adrian Achyar dan Kiki Oktora. 2014. The Antecedents and Effects of Relationship Quality, Satisfaction, Word-Of-Mouth, and Loyalty of Hajj and Umra Travel Agencies in Indonesia. The 8th International 
Conference on Business and Management Research (ICBMR), 2013, At Sungkyunkwan University, Seoul, Korea (South)

Akbar, M. M., \& Parvez, N. 2009. Impact of service quality, trust, and the customer can service quality, trust, and customer satisfaction on customers loyalty satisfaction engender customers loyalty?. Journal of Marketing 29(1) 24-38.

Alford dan Sherrell. 2016. SERVQUAL: A Multiple-ltem Scale for Measuring Consumer Perceptions of Service Quality. Journal of Retailing (Vol.4, p.1).

Amin Nouri Kouchi, Mansour Zarra Nezhad, Pouyan Kiani. 2016. A study of the relationship between the growth in the number of Hajj pilgrims and economic growth in Saudi Arabia. Journal of Hospitality and Tourism Management, http://dx.doi.org/10.1016/j.jhtm.2016.01.008

Andrew E. Wilson, Michael D. Giebelhausen, Michael K. Brady. 2017. Negative word of mouth can be a positive for consumers connected to the brand. Journal of the Academic Marketing Science. 45:534-547 DOI $10.1007 / \mathrm{s} 11747-017-0515-\mathrm{z}$

Babu, M.Naresh. 2014. The Impact of Celebrity Endorsement on Purchase Decision of Telecom Users- A Case of Engineering Students. Journal. Pondicherry Central University. Vol-1, Issue-2 pp. 289-305

Barber, B. 2013. The Logic and Limits of Trust. Rutgers UP. New Brunswick.

Byun, Eun Mo. 2014. Impact of K-Pop Celebrity Endorsement on Thai Brand Image. Journal. Chulalongkorn University. Vol 21 No. 1 February 2014, pp 134-147

Carlson, B., Donavan, D., 2008. Concerning the effect of athlete endorsements on brand and team-related intentions. Sports Marketing Quarterly. 1(7) 154-162.

Carrie, L., Sejung, M., 2015. The importance of perceived endorser credibility in South Korean advertising. Journal of Current Issues \& Research in Advertising. 27 (2) 67-81.

Cho, J. E., \& Hu, H. 2009. The effect of service quality on trust and commitment varying across generations. International Journal of Consumer Studies. 3(3) 468-476.

Choi, S.M. \& Rifon, N.J. 2007. Who is the celebrity in advertising? Understanding dimensions of celebrity images. Journal of Popular Culture. 40(2) 30425.

Cooper. D. R., \& Schindler. P. S. 2006. Bussiness Research Methods $\left(9^{\text {th }}\right.$ edition). USA: Mc Graw-Hill

Dick, A.S dan Basu, K. 2014. Customer Loyalty: Toward an Integrated Conceptual Framework. Journal of The Academy Marketing Science. 2(2) 99-113.

Eric Ng, Frances Cassidy, Les Brown. 2016. Exploring the major factors influencing consumer selection of travel agencies in a regional setting. Journal of Hospitality and Tourism Management, 13 (1). pp. 75-84. 
Friedman, H. H., \& Friedman, L. 2012. Endorser effectiveness by product type. Journal of Advertising Research. 1(9) 63-71

Ganesan, S., \& Hess, R. O. N. 2016. Dimensions and Levels of Trust: Implications for Commitment to a Relationship. Journal of Marketing 4(1) 439-448.1

Griffin, Jill. 2015. Customer Loyalty: How to learn it, How to keep it. Jakarta: Erlangga

Gul, R. 2014. The Relationship between Reputation, Customer Satisfaction, Trust, and Loyalty. Journal of Public Administration and Governance. Vol. 4, No. 3 (368-387).

Hur, W., \& Kim, M. 2013. Building Brand Loyalty Through Managing Brand Community Commitment, Journal of Interactive Marketing. 49(7) 11941213.

Jill Sweeney \& Joffre Swait. 2008. The effects of brand credibility on customer loyalty. Journal of Retailing and Consumer Services 15 (2008) 179-193

Kemenag.go.id. 2017

Khan, Shaista Kamal, Aroobah Rukhsar, Maria Shoaib. 2016. Influence of Celebrity Endorsement on Consumer Purchase Intention. Journal of Business and Management,18(1),pp:06-09

Kiki Oktora, Adrian Achyar. 2014. The Effect of Post Purchased Perceived Value Towards The Relationship Quality of Hajj and Umrah Travel Agencies in Indonesia. The South East Asian Journal of Management. April 2014. Vol 8. No. 1

Kotler, P, Armstrong, G, Wong, VWY \& Saunders, JA. 2008. Principles of marketing. 5th edn, Financial Times/Prentice Hall.

Leila Rahmani-Nejad, Zahra Firoozbakht, Amin Taghipoor. 2014. Service Quality, Relationship Quality and Customer Loyalty (Case Study: Banking Industry in Iran. Journal of Social Sciences, 2014, 2, 262-268

Morgan, R.M. and Hunt, S.D. 2009. The commitment-trust theory of relationship marketing. Journal of Marketing, Vol. 58 No. 3, pp. 20-38.

Muhammad Ashdaq, Haris Maupa, Muhammad Yunus Amar, Idayanti Nursyamsi. 2015. Analysis of Service Quality On Pilgrims Satisfaction And Image Of Hajj And Umrahs Travel Agents In South Sulawesi Province, Indonesia. International Journal of Research In Social Sciences. Aug. 2015. Vol. 5, No.6. ISSN 2307-227X

Nha Nguyen, André Leclerc, Gaston LeBlanc. 2013. The Mediating Role of Customer Trust on Customer Loyalty. Journal of Service Science and Management, 2013, 6, 96-109

Nick Johns, Turgay Avci dan Osman M. Karatepe. 2014. Measuring Service Quality of Travel Agents: Evidence from Northern Cyprus. The Service Industries Journal, Vol.24, No.3, May 2014, pp.82-100. ISSN 0264-2069

Ohanian, R. 2007. Construction and Validation of a Scale to Measure Celebrity Endorsers' Perceived Expertise, Trustworthiness, and Attractiveness, Journal of Advertising, 19(3), 39-52, Taylor \& Francis, Ltd., Oxfordshire. 
Riyad Eid. 2015. Integrating Muslim Customer Perceived Value, Satisfaction, Loyalty and Retention in the Tourism Industry: An empirical study. International Journal of Tourism Research, Int. J. Tourism Res., 17: 249260 (2015)

Riyad Eid. 2015. Towards A High-Quality Religious Tourism Marketing: The Case Of Hajj Service In Saudi Arabia. Tourism Analysis, Vol. 17, pp. 509-522. E-ISSN 1943-3999

Roshan Priyankara, Sudath Weerasiri, Ravindra Dissanayaka, Manoj Jinadasa. 2017. Celebrity Endorsement and Consumer Buying Intention With Relation to the Television Advertisement for Perfumes. International Journal In Applied Studies And Production Management. VOLUME 3, ISSUE 3 AUGUST 2017.

Roshana Gul. 2014. The Relationship between Reputation, Customer Satisfaction, Trust, and Loyalty. Journal of Public Administration and Governance ISSN 2161-7104 2014, Vol. 4, No. 3

Selda Ene dan Betül Özkay. 2014. A Study on Corporate Image, Customer Satisfaction, and Brand Loyalty in the Context of Retail Stores. International Journal of Humanities and Social Science Vol. 5, No. 1; January 2015

Sekaran, Uma \& Bougie, Roger. 2010. Research Method for Business A Skill Building Approach (5thEdition).United Kingdom: John Wiley \& Sons Ltd.

Seyed Alireza Mousavi dan Mahnoosh Ghaedi. 2012. A survey on the relationship between trust, customer loyalty, commitment and repurchase intention. African Journal of Business Management Vol. 6(36), pp. 10089-10098, 12 September 2012

Shaista Kamal Khan, Aroobah Rukhsar, Maria Shoaib. 2016. Influence of Celebrity Endorsement on Consumer Purchase Intention. IOSR Journal of Business and Management (IOSR-JBM) e-ISSN: 2278-487X, p-ISSN: 2319-7668. Volume 18, Issue 1.Ver. I (Jan. 2016), PP 06-09

Siti Hasnah Hassan, Amin Maghsoudi dan Nurul Illiyani Mohd Nasir. 2016. A conceptual model of perceived value and consumer satisfaction: a survey of Muslim travelers' loyalty on Umrah tour. Int. J. Islamic Marketing and Branding, Vol. 1, No. 3, 2016

Stanton, William, J. 2010. Principles Of Marketing. Ten Edition. McGraw Hill, Singapore. 